\title{
SISTEM PERINGATAN DINI BANJIR
}

\author{
Zahir Zainuddin ${ }^{1}$, Abdul Latif Arda ${ }^{2}$, Andi Zulkifli Nusri ${ }^{3}$ \\ Dept Teknik Informatika UNHAS ${ }^{1}$, Sistem Komputer STMIK HANDAYANI ${ }^{2,3}$ \\ Email : zainuddinzahir@gmail.com ${ }^{1}$, latiefbaruga2@yahoo.com ${ }^{2}$,andizulkifli51@gmail.com³
}

\begin{abstract}
ABSTRAK
Dengan adanya peringatan banjir dini, yang memanfaatkan web design dari sistem yang kami buat, maka akan lebih banyak waktu yang diberikan kepada warga untuk mempersiapkan diri sebelum bencana banjir tersebut datang, untuk merancang bangun suatu sistem peringatan dini banjir berdasarkan 3 level siaga 1, siaga 2 dan siaga 3 dengan memanfaatkan curah hujan dan ketinggian air dan Mikrokontroler Wemos D1 R1 sebagai pemproses data. Berdasarkan pengujian yang digunakan, di kedua sensor tersebut telah mampu berfungsi sebagai sistem penghitung curah hujan atau tipping bucket dan sistem pengukur tinggi permukaan air sungai atau ultrasonic sensor.Sistem berhasil mengunggah data ke website dan menampilkan peta lokasi penempatan sensor. Tipping bucket berhasil berjalan dengan tingkat error maksimal 7\%. Sedangkan sensor jarak berhasil berjalan dengan error maksimal 19\%
\end{abstract}

\section{Kata Kunci: Sensor Hujan,Ultrasonic sensor, Website}

\begin{abstract}
With the early flood warning, which utilizes the web design of the system we made, more time will be given to residents to prepare themselves before the flood disaster comes, to design and build a flood early warning system based on 3 levels of alert 1, standby 2 and standby 3 by utilizing rainfall and water level and Wemos DI RI Microcontroller as data processing.

Based on the tests used, the two sensors have been able to function as a tipping bucket rainfall system and a river water level measurement system or ultrasonic sensor. The system successfully uploaded data to the website and displayed a map of the location of the sensor. Tipping bucket successfully runs with a maximum error rate of 7\%. While the proximity sensor runs successfully with a maximum error of $19 \%$.
\end{abstract}

Keywords: Rain Sensor, Ultrasonic sensor, Website

\section{PENDAHULUAN}

Banjir sebenarnya dapat dikatakan sebagai fenomena alam "biasa" karena hampir semua negera pernah dan bahkan rutin mengalaminya, termasuk Indonesia. dan dalam skala tertentu banjir juga sudah dikatagorikan sebagai bencana besar karena menimbulkan korban jiwa yang tidak sedikit. Salah satu jenis banjir yang rutin terjadi adalah banjir yang disebabkan luapan air sungai, banjir juga biasa terjadi karena akibat dari derasnya hujan di daerah hulu dan mengakibatkan luapan air sungai pada hilir sungai.

Banjir jenis ini umumnya berdampak terhadap penduduk yang berada di sekitar bantaran sungai. Bila luapan air sungai ini terjadi pada siang hari, maka dampaknya terutama korban jiwa mungkin dapat 
diminimalisir karena penduduk dapat mengetahui dan menyadari kehadiran bencana tersebut. Masalahnya menjadi lain ketika banjir terjadi pada malam hari, ketika penduduk sedang tertidur lelap, berdasarkan permasalahan yang ada, maka penulis mengusulkan untuk mengembangkan alat sistem peringatan dini banjir yang di butuhkan pada lokasi rawan banjir.

Penelitian sebelumya yang telah dilakukan oleh Pradhana (2011) Pembacaan ketinggian level air dan kecepatan aliran air dengan memanfaatkan sensor elektroda, optocoupler, dan mikrokontroller ATmega8535 dan dikirim SMS gateway. Data ketinggian level air dan kecepatan aliran air dikirim secara otomatis melalui handphone dari transmitter kereceiver. Data yang diterima receiver di olah oleh mikrokontroller yang akan ditampilkan pada LCD dan dalam bentuk suara (ISD25120) melalui pengeras suara.

Sedangkan penelitian Nurdianto, (2018) Secara garis besar sistem kendali alat peringatan dini banjir ini menggunakan mikrokontroler Wemos D1 R1 ESP 8266, dibagi dalam dua bagian yaitu perancangan hardware dan software. Untuk bagian perangkat keras terdiri dari catu daya sebagai sumber energi dari semua sistem pada alat, mikrokontroler Wemos D1 R1 yang berfungsi sebagai pengolah data (processor) dan pengontrol dari seluruh sistem, buzzer berfungsi sebagai indikator berupa suara.

Dari penelitian yang dilakukan oleh Pradhana (2011) dan Nurdianto (2018) yang membedakan dengan penelitian yang akan dilakukan adalah output level ketinggian air dan curah hujan serta lokasi pemasangan sensor ditampilkan pada website, sedangkan bunyi tiap level banjir yang di buat peneliti berbeda tiap levelnya.

Hal tersebut di atas menarik perhatian pada penulis untuk melakukan suatu penelitian yang diharapkan dapat membantu penduduk menyadari bahaya banjir yang akan segera tiba.

\section{LANDASAN TEORI}

\subsection{Sensor Ketinggian Level Air}

Sensor ketinggian level air sungai yang digunakan pada penelitian ini menggunakan prinsip kerja hukum pemantulan gelombang bunyi (gelombang ultrasonik), yang dimanfaatkan sebagai media untuk menghitung level ketinggian air sungai. Gelombang Ultrasonik adalah gelombang yang mempunyai besaran Sensor ketinggian level air sungai yang digunakan pada penelitian ini menggunakan prinsip kerja hukum pemantulan gelombang bunyi (gelombang ultrasonik), yang dimanfaatkan sebagai media untuk menghitung level ketinggian air sungai. Gelombang Ultrasonik adalah gelombang yang mempunyai besaran frekuensi lebih dari $20 \mathrm{KHz}$ dan bekerja berdasarkan pantulan gelombang suara. Gelombang ultrasonik bisa merambat pada medium padat, cair dan gas (Musthofa, 2014).

\subsection{Sensor Curah Hujan (Tipping-bucket)}

Tipping Bucket adalah salah satu alat yang digunakan untuk merekam data intensitas curah hujan. Data curah hujan merupakan input utama untuk model simulasi curah hujan-aliran permukaan (rainfall-runoff) untuk aplikasi hidrologi perkotaan. Desain dan analisis sistem drainase perkotaan sangat dipengaruhi oleh ketidakpastian data intensitas curah hujan dan durasi yang tercatat (Evita et al., 2011). 
Dengan dimensi yang sudah tertulis diatas, luas lingkaran pada corong adalah $176.71 \mathrm{~cm} 2$. Sedangkan untuk penadah yang dibuat mampu bergerak dengan volume air sebesar 3-4mL. Untuk linci hujan adalah $2,54 \mathrm{~cm}$ sehingga per linci hujan dengan asumsi volume penadah $4,5 \mathrm{ml}$ adalah $448.84 \mathrm{~cm} 3$ atau $\mathrm{mL}$. Untuk $4.5 \mathrm{~mL}$ adalah 0,010025 inci hujan. 0,010025 inci hujan adalah $0,254 \mathrm{~mm}$. Diasumsikan tipping bucket yang penulis buat memiliki ketelitian per $0,25 \mathrm{~mm}$.

\section{METODE PENELITIAN}

3.1 Identifikasi Masalah

Proses pembuatan sistem peringatan dini banjir ini diperlukan identifikasi masalah untuk mengetahui kebutuhan terhadap sistem yang akan dibuat, diantaranya : rangkaian mekanik, rangkaian sistem arduino sebagai rangkaian pengendali input dan output, rangkaian penyuplai tegangan, sensor untuk level Ketinggian permukaan air dan curah hujan.

3.2 Design dan Perancangan Alat

1) Perancangan Elektronik

Perancangan elektronik adalah perancangan komponen-komponen elektronik yang terdiri dari mikrokontroller Wemos D1 R1, sensor, LCD dan catu daya menjadi sebuah rangkaian yang bertujuan untuk menghitung Level ketinggian air dan curah hujan yang hasilnya ditampilkan melalui LCD, dan di publikasikan di Web

2) Perancangan Sofware

Perancangan software adalah perancangan perangkat lunak berupa perintah untuk ketinggian air dan curah hujan yang dideteksi oleh sensor kemudian menampilkan hasil perhitungan ke LCD dan web.
Perancangan software ini menggunakan aplikasi IDE Arduino.

3.3 Rancangan Sistem

Berikut ini adalah rancangan sistem tentang peringatan dini banjir,Dengan merancang alat curah hujan dan ketinggian air sebagai akuisisi data dalam pengambilan keputusan yaitu peta aliran sungai yang meluap yang dapat deteksi dini banjir .

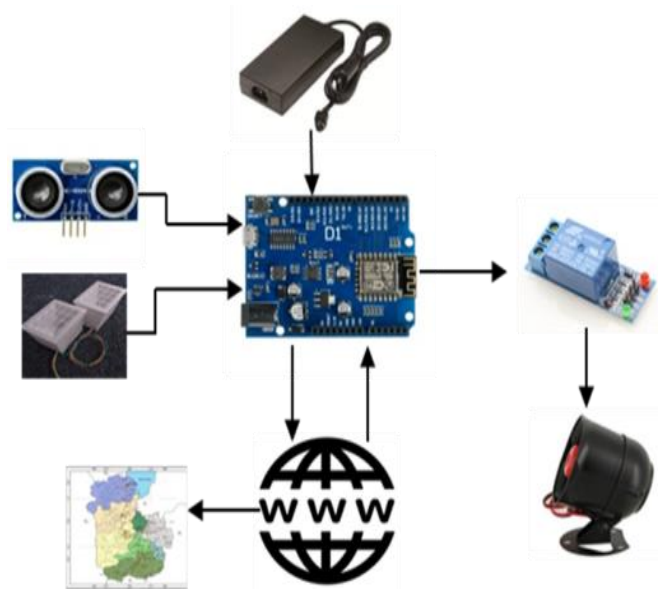

Gambar 1. Blok diagram sistem peringatan dini banjir

\section{HASIL DAN PEMBAHASAN}

4.1 Hasil Perancangan / Rekayasa

Setelah memalui beberapa tahapan perancangan yang meliputi, perancangan elektronik dan perancangan program mikrokontroler maka telah dihasilkan suatu alat yakni "Sistem peringatan dini banjir"

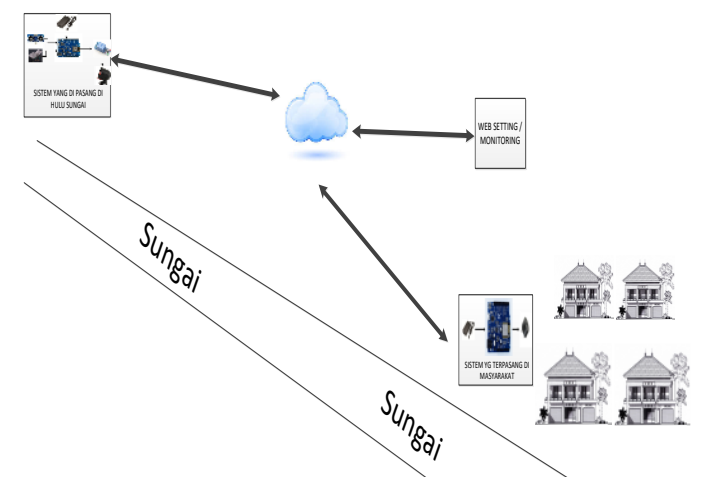

Gambar 2. Gambaran Sistem seluruhnya 


\subsection{Rangkaian Schematic}

1) Gambar rangkaian schematic yang pertama

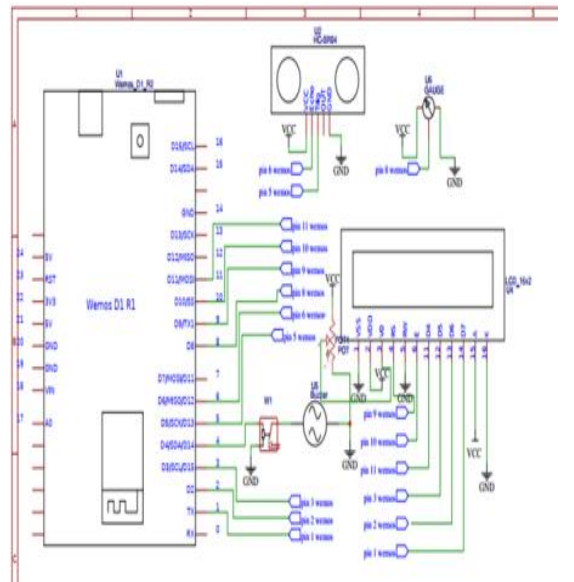

Gambar 3. Skematik Sistem

Peringatan Dini Banjir yang pertama

2) Gambar rangkaian schematic yang kedua

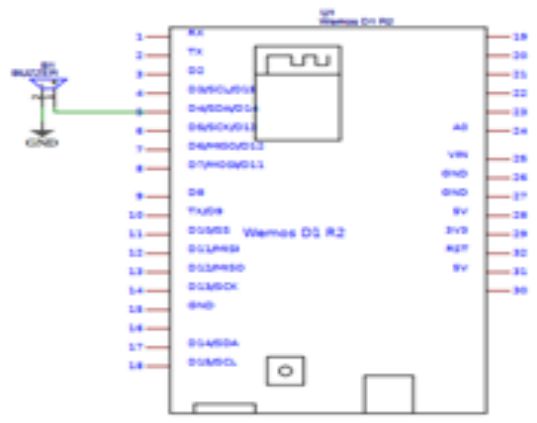

Gambar 4. Skematik Sistem peringatan dini banjir yang kedua

\subsection{Perangkat Lunak}

Perancangan perangkat lunak merupakan perancangan pemograman yang akan digunakan untuk menjalankan sistem yang nantinya akan ditanamkan pada mikrokontroler dan untuk membuat sistem antarmuka pada pada website Rancangan perangkat lunak pada penelitian ini menggunakan IDE Arduino 1.8.10, implementasi antarmuka dari system teknologi Node-red untuk layanan peringatan dini banjir.
1) System teknologi Node - Red Tampak pada tampilan login, dapat terlihat pada gambar berikut:

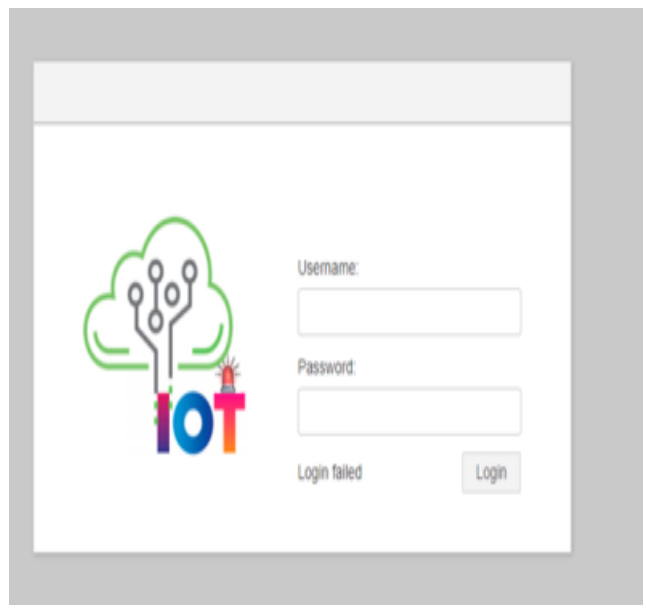

Gambar 5. Tampak pada tampilan login Node - Red

2) Implementasi Sofware Back End

Perangkat lunak back end yang berfungsi untuk menyimpan data sensor mengambil informasi level ketinggian air dan curah hujan dan melakukan fungsi - fungsi komunikasi lainnya seperti memicu alarm dan tiap level siaga memiliki bunyi peringatan yang berbeda.

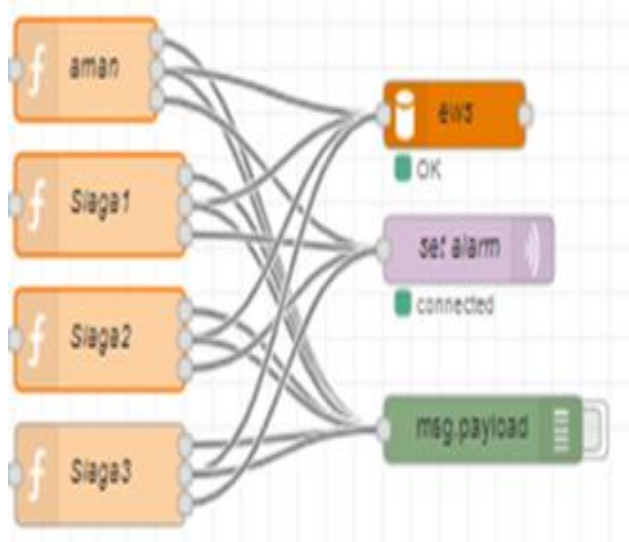

Gambar 6.Tampilan tool komunikasi alarm

3) Impelementasi software Front End Pada front end penulis mengimplementasikan tampilan 
aplikasi menggunakan php java script html dan css untuk menampilkan status sensor dan peta lokasi pemasangan sensor. Pekerjaaan umum yang akan berhubungan dengan lapisan front-end adalah web designer atau perancang web di tunjukkan pada gambar berikut

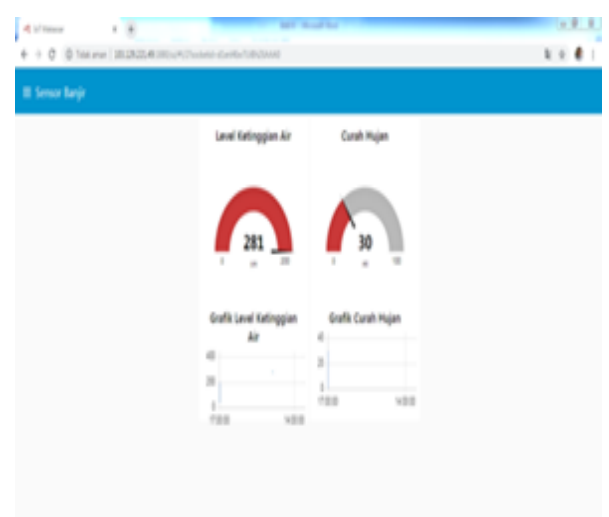

Gambar 7. Node - Red Dashboard Sensor Banjir

4) Pemrograman pada Arduino dan Wemos

Diagram alir pemograman pada Arduino dan Wemos dapat dilihat pada gambar dibawah ini

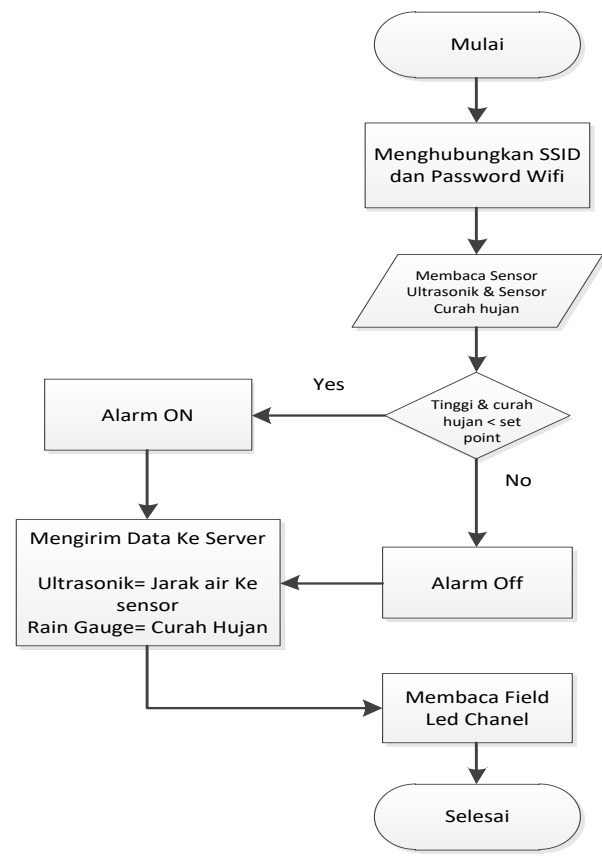

Gambar 8. Diagram Alir Pemrograman pada Arduino dan Wemos
5) Pemprograman antar muka

Diagram alir pemograman antar muka dapat dilihat pada gambar dibawah ini

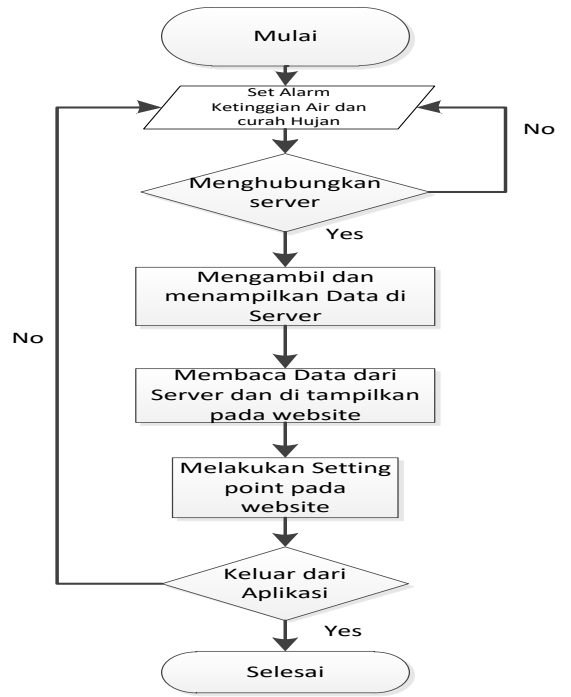

Gambar 9. Diagram alir pemograman antar muka

\subsection{Pengujian Sensor Ultrasonik}

Untuk melakukan pengujian sensor ultrasonik, digunakan pengujian sederhana di sebuah wadah tempat air. Jarak terjauh yang mampu di deteksi adalah $200 \mathrm{~cm}$. Jarak terendah adalah $2 \mathrm{~cm}$. Sementara pengujian dilakukan pada wadah tempat air yang memiliki tinggi maksimal $60 \mathrm{~cm}$. Format data yang di ambil oleh sensor adalah float

Tabel 1. Pengujian sensor ultrasonik

\begin{tabular}{cccc}
\hline $\begin{array}{c}\text { Pengukuran } \\
\text { dengan alat }\end{array}$ & $\begin{array}{c}\text { Penguk } \\
\text { uran } \\
\text { dengan } \\
\text { sensor }\end{array}$ & $\begin{array}{c}\text { Akurasi } \\
(\%)\end{array}$ & $\begin{array}{c}\text { Error } \\
(\%)\end{array}$ \\
\hline $60 \mathrm{~cm}$ & $60 \mathrm{~cm}$ & $100 \%$ & $0 \%$ \\
$55 \mathrm{~cm}$ & $55 \mathrm{~cm}$ & $100 \%$ & $0 \%$ \\
$50 \mathrm{~cm}$ & $48 \mathrm{~cm}$ & $96 \%$ & $4 \%$ \\
$45 \mathrm{~cm}$ & $43 \mathrm{~cm}$ & $95 \%$ & $5 \%$ \\
$40 \mathrm{~cm}$ & $38 \mathrm{~cm}$ & $96 \%$ & $2 \%$ \\
$35 \mathrm{~cm}$ & $33 \mathrm{~cm}$ & $94 \%$ & $6 \%$ \\
$30 \mathrm{~cm}$ & $31 \mathrm{~cm}$ & $93 \%$ & $7 \%$ \\
$25 \mathrm{~cm}$ & $24 \mathrm{~cm}$ & $96 \%$ & $4 \%$ \\
\hline
\end{tabular}


Akurasi tertinggi dalam pembacaan sensor ultrasonik adalah $100 \%$. Sedangkan error tertinggi adalah 7\%. Error terjadi karena tidak diketahuinya kondisi stabil dari permukaan air yang diakibatkan oleh geraknya gelombang air. Hal ini mampu diatasi apabila gelombang air bergerak dengan tidak cukup besar sehingga tidak mengganggu permukaan air. Pada bagian ini juga tidak ada kendala dalam pengiriman data pada server.

\subsection{Sensor curah hujan (Tipping Bucket)}

Untuk pengujian Tipping Bucket akan dibagi menjadi beberapa bagian. Bagian pertama adalah pengujian dengan mengalirkan air dalam volume tertentu pada Tipping Bucket, kemudian akan dianalisa seberapa tingkat akurasi Tipping Bucket terhadap air tersebut.Pengujian kedua pengujian di dunia nyata dimana untuk pengujian ini tidak dibandingkan dengan apapun karena di lokasi yang dipilih tidak terdapat tipping bucket atau alat pembanding lainnya.

Tabel 2. Pengujian dengan volume air tertentu

\begin{tabular}{|c|c|c|c|c|}
\hline $\begin{array}{l}\text { Volu } \\
\text { me air } \\
(\mathrm{ml})\end{array}$ & $\begin{array}{c}\text { Gera } \\
\text { kan } \\
\text { TB }\end{array}$ & $\begin{array}{l}\text { Volume } \\
\text { yang } \\
\text { dibaca } \\
\text { TB }\end{array}$ & $\begin{array}{c}\text { Kete } \\
\text { litia } \\
\mathrm{n} \\
(\%)\end{array}$ & $\begin{array}{c}\text { Error } \\
(\%)\end{array}$ \\
\hline $100 \mathrm{ml}$ & $\begin{array}{c}18 \\
\text { kali }\end{array}$ & $81 \mathrm{ml}$ & $81 \%$ & $19 \%$ \\
\hline $200 \mathrm{ml}$ & $\begin{array}{c}51 \\
\text { kali }\end{array}$ & $229.5 \mathrm{ml}$ & $87 \%$ & $13 \%$ \\
\hline $300 \mathrm{ml}$ & $\begin{array}{c}74 \\
\text { kali }\end{array}$ & $333 \mathrm{ml}$ & $90 \%$ & $10 \%$ \\
\hline $400 \mathrm{ml}$ & $\begin{array}{c}91 \\
\text { kali }\end{array}$ & $409.3 \mathrm{ml}$ & $98 \%$ & $2 \%$ \\
\hline $500 \mathrm{ml}$ & $\begin{array}{l}112 \\
\text { kali }\end{array}$ & $504 \mathrm{ml}$ & $99 \%$ & $1 \%$ \\
\hline
\end{tabular}

Dari tabel dan grafik yang sudah tercantum diatas, ketelitian tertinggi yang mampu dibaca oleh tipping bucket adalah 99\% sedangkan error tertinggi yang dimiliki tipping bucket adalah 19\%. Error sendiri terjadi karena tingkat ketelitian yang tidak sama antara Gelas Ukur dan Tipping bucket sendiri. Tidak ada kegagalan dalam pengiriman ke server .

4.6 Pengujian alarm per level

Tahapan ini disimulasikan seperti berikut jika level ketinggian permukaan air terhadap sensor ultrasonik $140 \mathrm{~cm}$ dan curah hujan $1 \mathrm{~mm}$ maka alarm pada siaga 1 akan berbunyi, jika level ketinggian permukaan air terhadap sensor ultrasonik $100 \mathrm{~cm}$ dan curah hujan $2 \mathrm{~mm}$ maka alarm pada siaga 2 akan berbunyi, jika level ketinggian permukaan air terhadap sensor ultrasonik $40 \mathrm{~cm}$ dan curah hujan $3 \mathrm{~mm}$ maka alarm pada siaga 3 akan berbunyi dan tiap tingkatan level mempunyai bunyi yang berbeda.

Tabel 3 Pengujian Alarm Per Level

\begin{tabular}{|c|c|c|c|}
\hline $\begin{array}{c}\text { Level } \\
\text { ketinggian } \\
\text { air }(\mathrm{cm})\end{array}$ & $\begin{array}{c}\text { Curah } \\
\text { hujan } \\
(\mathrm{ml})\end{array}$ & Status & Alarm \\
\hline 200 & 0 & Aman & Off \\
\hline 140 & 1 & $\begin{array}{c}\text { Siaga } \\
1\end{array}$ & $\begin{array}{c}\text { Bunyi } \\
1 \mathrm{x}\end{array}$ \\
\hline 100 & 2 & $\begin{array}{c}\text { Siaga } \\
2\end{array}$ & $\begin{array}{c}\text { Bunyi } \\
2 \mathrm{x}\end{array}$ \\
\hline 40 & 3 & $\begin{array}{c}\text { Siaga } \\
3\end{array}$ & $\begin{array}{c}\text { Bunyi } \\
3 \mathrm{x}\end{array}$ \\
\hline
\end{tabular}

\subsection{Pengujian transmisi data}

Proses transmisi data oleh sistem peringatan dini banjir ke web server juga menjadi focus pengujian pada penelitian ini. Sistem peringatan dini banjir akan mengirim data ke web server dan akan ditampilkan ke web yang telah dibuat. 


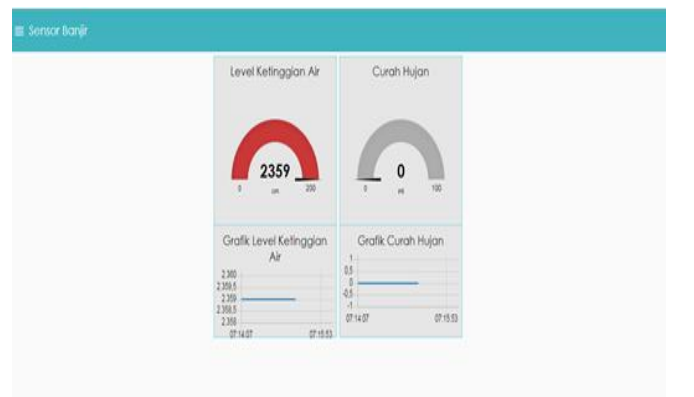

Gambar 10. Tampilan Awal pada website

Pada Website dapat melakukan set alarm untuk peringatan dini banjir dengan memasukkan set tinggi jarak air ke sensor dan set curah hujan,di website jg dapat mengatur level ketinggian air dan curah hujan. Mulai dari level 1,level 2 dan 3 dapat di atur ketinggian air ke sensor dan curah hujan dan akan memunculkan peta lokasi pemasangan sensor, untuk menampilkan Jarak air ke sensor,curah hujan dan set alarm ke server.

\section{SIMPULAN DAN SARAN}

\subsection{Simpulan}

Berdasarkan hasil pengujian dan analisis sistem yang di bangun dapat di ambil kesimpulan sebagai berikut :

1) Penggunaan kedua sensor untuk pengembangan dengan jumlah lebih besar dinilai sangat baik karena keseluruhan sistem sangat murah, mudah dicari dan mudah untuk dikembangkan. Sehingga untuk pengembangan alat ini ke daerah rawan banjir bisa dipertimbangkan.

2) Pembacaan jarak sensor ke air dan sensor curah hujan yang ditampilkan pada web dan muncul peta yang sesuai dengan level set yang sudah di setting pada web.

5.2 Saran

Terlepas dari kelebihan - kelebihan, sebuah system peringatan dini banjir pastinya memiliki kekurangan ,maka dari itu untuk pengembangan lebih lanjut merupakan saran - saran yang dapat diberikan adalah sebagai berikut :

1) Penggunaan catu daya cadangan yang jauh lebih besar karena daerah pos tidak selalu terdapat sumber listrik mengingat terdapat juga pos-pos yang berada di daerah-daerah kurang sumber listrik.

2) Di perlukan rancangan yang lebih teliti lagi agar rangkaian ini dapat bekerja lebih sempurna.

\section{DAFTAR PUSTAKA}

Evita, M., Mahfudz, H., Suprijadi, S., Djamal, M., \& Khairurrijal, K. (2011). Alat Ukur Curah Hujan Tipping-Bucket Sederhana dan Murah Berbasis Mikrokontroler. Jurnal Otomasi Kontrol Dan Instrumentasi, 2(2), 69.

Musthofa, A. K. (2014). Sistem Monitoring Ketinggian Air Sungai Menggunakan Sensor Ultrasonik Berbasis Mikrokontroler 8535. Skripsi Sarjana, Fakultas Teknologi Industri Institut Teknologi Adhi Tama Surabaya, Surabaya

Nurdianto, A. (2018). Rancang Bangun sistem Peringatan Dini Banjir (EARLY WARNING SYSTEM) Terintegrasi Internet Of Things. Jurnal Online Mahasiswa (JOM) Bidang Teknik Elektro, 1(1).

Pradhana, A. (2011). Peringatan Dini Bahaya Banjir Di Tambang Pasir Berbasis SMS Gateway, Program Studi Instrumentasi Dan Elektronika, Jurusan Fisika, Fakultas Matematika Dan Ilmu Pengetahuan Alam, Universitas Diponegoro, Semarang 